\title{
The Analysis of Local Marketplace Business on the Selected Urban Case-Problems and Perspectives
}

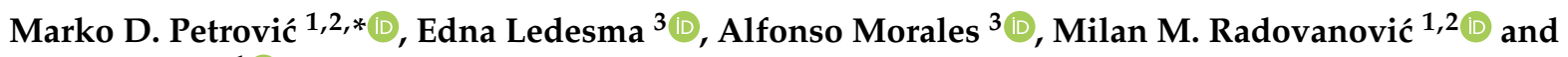 \\ Stefan Denda ${ }^{1} \mathbb{D}$ \\ 1 Geographical Institute "Jovan Cvijić" of the Serbian Academy of Sciences and Arts, 11000 Belgrade, Serbia; \\ m.radovanovic@gi.sanu.ac.rs (M.M.R.); s.denda@gi.sanu.ac.rs (S.D.) \\ 2 Institute of Sports, Tourism and Service, South Ural State University, 454080 Chelyabinsk, Russia \\ 3 Department of Planning and Landscape Architecture, University of Wisconsin-Madison, \\ Madison, WI 53706, USA; eledesma@wisc.edu (E.L.); morales1@wisc.edu (A.M.) \\ * Correspondence: m.petrovic@gi.sanu.ac.rs
}

check for

updates

Citation: Petrović, M.D.; Ledesma, E.; Morales, A.; Radovanović, M.M.; Denda, S. The Analysis of Local Marketplace Business on the Selected Urban Case-Problems and Perspectives. Sustainability 2021, 13, 3446. https://doi.org/10.3390/ su13063446

Academic Editors: Alfonso Morales and Mark A. Bonn

Received: 1 February 2021

Accepted: 9 March 2021

Published: 20 March 2021

Publisher's Note: MDPI stays neutral with regard to jurisdictional claims in published maps and institutional affiliations.

Copyright: (c) 2021 by the authors. Licensee MDPI, Basel, Switzerland. This article is an open access article distributed under the terms and conditions of the Creative Commons Attribution (CC BY) license (https:/ / creativecommons.org/licenses/by/ $4.0 /)$.

\begin{abstract}
Local marketplaces and street vendors represent an important segment of trade in a community and one of the initiators of the rural and peri-urban development. Agricultural and other products available at marketplaces and street vendors very often originate from a wider urban surrounding or nearby villages, so both are also an important factor of the daily migrations, exchange of goods, services, and money on the relation suburb-downtown and village-town/city. This study aims to analyze the social segments of the organization and operation of marketplaces, to provide an insight into the contemporary market processes and decision-making, and also to illustrate the future tendencies of the market outcomes of this aspect of the business. Using qualitative data processing, the results of one of the first empirical research on this topic in Serbia and this part of Europe will be analyzed. The results will show the economic, social, and cultural impact that marketplaces have on people's everyday life and the economy of Serbia, along with defining future development guidelines. Besides, the findings of this research may be used by local authorities, the economy, and communities for future strategic development planning of this market segment. The outcomes may have an impact on future research of other aspects of marketplaces depending on the difference of regions, on one side, and also alternative opportunities for local development in less-advantaged communities, on the other side. Moreover, this contributes to the identification of the differences in the marketplace business management and sheds light on future initiatives for the encouragement of this local/global process.
\end{abstract}

Keywords: marketplaces; street vendors; Novi Sad; social organization; market processes and outcomes

\section{Introduction}

Throughout history, the human population has developed various forms of goods exchange. This process was realized in various circumstances and places, among which local marketplaces had a tremendous role. It was one of the most important segments of selling local products in most of the countries. The terms market and marketplace originate from the Persian word bazaar (Turkish pazar or Serbian pazar, pijaca or tržnica) meaning an open public space where buyers and sellers meet at certain times for commercial purposes [1]. They appeared almost at the same time as the first exchanges of goods, i.e., when people, faced with the fact that they had something more than they needed, and had something in small quantities or lacked it completely, spontaneously formed places where they could exchange their goods [2]. They are specially assigned and arranged spaces where goods and services are sold, and they are usually located in the center of urban/rural settlements surrounded by institutions of local power [3]. Therefore, marketplaces are defined as indoor or outdoor locations where vendors gather periodically to sell merchandise [4]. Moreover, different forms of marketplaces are distinguished, such as open-air marketplaces, street 
marketplaces (official and unofficial), purpose-built marketplaces, periodic marketplaces, flea marketplaces, permanent and mobile marketplaces, public marketplaces, municipal marketplaces, and swap meets [5]. Also, depending on the goods sold there, the stands are equipped with scales, a cash register, and products' displayed prices [6]. Marketplace goods are primarily sold by their owners (farmers, cattle breeders, fishermen, etc.), where vendors operate as entrepreneurs. It is known that business creation for merchants at markets is faced with minimal barriers [4], which allow people to develop skills and expand capital incrementally [4,7-10]. Contrary to other stores and commercial firms, bargaining between a buyer and a seller is often allowed about the most favorable price, and the prices can change many times in a day-depending on the offer and demand. In most of the developed countries, marketplace vendors are recorded and registered as producers or as taxpayers [11]. On the other side, marketplaces are much more than commercial gathering places that city authorities sometimes consider them [12]. Namely, they can be observed as the earliest and most represented form of public and social activity [1]. Besides, Morales [4] stated that "marketplaces manifest people's purposes and perceptions. Ostensibly, they are periodic and place-based events hosting small businesses and consumers" (p. 3).

Bearing in mind the role of the marketplaces in the gentrification process, the European Union has launched the "Urban Markets" project in 2013. The urban markets as key drivers of change of cities (economic, social, and cultural) provide a new model of regeneration and sustainable living $[3,10,13]$. The real estate conditioned the trend of the forced relocation of street market structures as undesirable urban actors in newly developed "trade areas" where their business is often predisposed to fail $[14,15]$. The relocation of street economies to permanent location brings great value to land development. So while marketplaces have evolved and adapted, what has remained constant has been the need for societies to provide a place for the interaction of people through the transaction. Therefore, in this paper, the evolution of one type of marketplace in Serbia has been examined, as an area with limited studies and an obvious research gap on this topic. Taking into account the mentioned facts, an example of a marketplace operated by a public utility company has been analyzed. The objective of the research is focused on the social organization of marketplaces and their actual state and management on the example of "Detelinarska pijaca" marketplace in Novi Sad, as one of the largest and well-known urban marketplaces in Serbia. The aim is to identify the differences and similarities in the marketplace business management conditioned by market trends by using qualitative methods such as interviews and participant-observation.

\section{The Overview on Marketplaces' Development on the Global Scale}

Marketplaces began about five thousand years ago with the development of exchange trade. From their beginning until today, marketplaces have been a barometer of socioeconomic circumstances in the areas where they have existed. For centuries, markets, occurring openly in town centers, provided people with a free social space as well as access to food [16]. They were one of the most important urban spaces in traditional societies. The existence of a "central market", as well as town halls, churches and others forms of civil power, were engines of urban growth, development, and providing sustainability in the economy $[12,17]$. Across European historical centers, traditional marketplaces were usually located at major intersections making the backbone of the entire physical structure of the city and its urban morphology [18]. City markets evolved to be a civic amenity that in many cases appeared as multipurpose infrastructure, working at the confluence of transportation networks, and at geographically robust locations. The first historical forms of marketplace activity were fairs/fairgrounds (which represent the forerunners of marketplaces in today's sense of the word), which have survived in some places even today as a part of the tradition of people's gathering, most often on Sundays or at the time of religious holidays. Fairs are an integral part of the history of marketplace activity of every larger settlement in Europe, and their more intense development was recorded in the 18th century [19]. These central square markets were points of exchange between 
the urban and rural economies in the pre-industrial period in most of Europe. During one or two weekly market days, farmers from the surrounding countryside provided a wide range of products to the urban population (e.g., vegetables, meat, fish, fodder, and firewood, etc.) [20]. According to the London County Council, in 1893, 112 street markets were registered, comprising 5292 stalls. In a later period, the number of market stalls in London grew substantially reaching 8000 in 1932 [21]. Later, industrial changes and modernization processes in the 19th century conditioned the markets to become arenas of conflicting interests for public space between traders and the state (public benefit versus private entrepreneurship) [12,22]. At the same time, the strengthening of department stores and other forms of trade has led to a reduction in official state support.

In the United Kingdom, the Netherlands, Hungary, and other countries, especially in the second half of the 20th century, there has been a reduction in investment followed by the organizational transformation of these areas. This is evidenced by the fate of downtown Boston's Quincy Market and New York City's South Street Seaport. Their conversion was a catalyst for gentrifying neighborhoods (exclusive private housing), rather than improving conditions and creating benefits for vulnerable groups in society [12]. The attitude of city officials that they represent a major health and safety problem (infectious diseases, noise, traffic congestion, and urban mess) contributed to this condition $[3,12]$. Subsequently, marketplaces all over the world faced difficult times [3].

Since the 1980s, the question of the exclusive role of the market as an economic category has been raised. Their original role was reflected in job creation (including informal employment), accumulation of wealth, income for traders and their families, and entrepreneurial skill development $[5,23,24]$. In addition to economic functions, traditional marketplaces were crucial localities for social, cultural, political, and religious activities [18]. In social terms, they represent spaces for mobility, solidarity, and social inclusion $[4,10,22]$. They contribute to many societal benefits including capital building, facilitation of social interaction, development of social capital, as well as a stronger sense of connection between consumers and the local community [24]. On the other hand, their cultural role is not negligible either. The voluntary contact creates the preconditions for cultural exchange among different ethnic backgrounds and nationalities [23] enabling familiarity and acceptance of the ritual activity of different cultural groups sharing public space $[1,25]$. They are a kind of cultural activity generators, a place of cultural heritage, transmitting local history, culture, and traditions [3]. In a word, they represent the pulse, heart of the city, the sense of life that best describes it [12,18].

One example of their adaptability has been ownership. Generally, they are operated by one of three entities: public, private, or public-private partnerships. For a long time, marketplaces as a physical location, grand, iconic building ("the city market") were typically operated by the state. This is also indicated by the examples of the UK. In the mentioned case, using legal instruments, the Corporation of London with a monopoly position governed the small central area in ancient London and belonging markets (e.g., Smithfield, Leadenhall, and Billingsgate markets). Although there were certain competencies for the reaction of the city authorities in the period 1817-1869, the mentioned issue was defined in detail during the 20th century. Namely, the legislation that referred to the street markets was incorporated in 1927 allowing the authorities to license street market traders [21]. Today, a key distinction is whether the land on which a marketplace operates is publicly or privately owned. However, researchers do not have a good understanding of the role that each of the three entities has in producing socially relevant benefits, and there is a need to further research all marketplace types [4].

The two constant features of the marketplace activity, which have not changed throughout history, are the vitality and adaptability to various business conditions. The changes in the market, according to unwritten rules, are first noticed by vendors in marketplaces. Primarily because they recognize and use the benefits of direct and immediate contact with their buyers, which is also another key characteristic of marketplaces that differs them from other, modern forms of trade. Marketplaces are a market, but they are also 
places for gathering and social interaction amongst people—-both in rural and in urban environments [6].

All the mentioned features and characteristics of marketplaces have their roots in the rich history and tradition of this activity. Following the changes in the way of living and with the technological development, marketplaces have had to adapt. In the last several decades, the largest changes in the activity of marketplaces have evolved as a direct consequence of the establishment of new, organized forms of providing the population with various items, among others, with groceries, as is the case of supermarkets. The growth of the supermarkets and megastores contributed to the decline in marketplaces [26,27]. These became contemporary forms of trade offered the population of urban areas an alternative to marketplaces. The changes also occurred in wholesale trade and retail trade [28], offering new shopping environments and transformed consumers from casual buyers to pleasure shoppers [17]. Technological advances, such as refrigeration and air conditioning, rail and road infrastructure, and goods-vehicles facilitated the expansion of private grocery stores to further territories through mass distribution of products that were, for a long time, only accessible locally.

However, despite the growth of multinational retail chains and online shopping, they still provide affordable food and work (more favorable forms of consumption and production) for millions of people across the world [22]. In a contemporary context, street vending is organized in large clusters in form of an urban bazaar as a place of intersection of cultures, values, symbols, interactions, interpretations, and activities [29]. In that respect, many markets across the world (e.g., La Boquerı'a Market in Barcelona, Rotterdam's Market Hall, Borough Market in London, or wet markets in Hong Kong) have even become destinations for tourists [22]. However, a major challenge for this area is the existing COVID-19 crisis, which has caused a number of organizational changes, requiring business in a highly regulated and controlled manner [30,31], including the observed urban marketplace.

\section{Short Background on Serbian Case}

Farmers have traditionally been connected with marketplaces in Serbia, which have represented the main gathering place of buyers and sellers throughout history, as well as a part of the social life of the local population and a psychological component of connecting within a community. Even today, marketplaces are important meeting points that offer agricultural and other products, so it is understandable why the government is interested in keeping the competitive advantages of marketplaces in comparison with supermarkets and distribution chains, which are the newest market actors in the trade of agricultural products [32]. The tradition of buying in marketplaces, which has been cherished in these regions for centuries, also has a significant sociological aspect.

In Serbia, marketplaces, as places for retail trade, are still a dominant form of a marketplace activity. Contrary to the majority of European countries, Serbia, which was delayed at entering the late 20th century economic transition process still does not have a wholesale marketplace. Wholesale trade of fruit and vegetables is performed on so-called "kvantaš" marketplaces, in the open spaces, where producers and vendors offer their products from trucks, trailers, or other vehicles. However, in 2012, the Declaration on the Cooperation on the Construction of the System of the National Wholesale Marketplace in Belgrade, the capital city of Serbia was signed. The National Wholesale Marketplace will cover the area of about 18 hectares, $17,000 \mathrm{~m}^{2}$ of which is the inside area, 750 parking spaces for trucks, and 500 parking places for buyers, loading and unloading ramps, forklift service, waste recycling section, hospitality facilities, and financial institutions. The expected annual turnover is 800 thousand to a million tons of goods [33]. This example is one more proof that, once again, the marketplace activity in Serbia entered the $21^{\text {st }}$ century with the need to adjust to another wave of changes. The process started almost simultaneously with the first signal of changes on the market, and the pace is not always in accordance with the needs, expectations, and wishes of both marketplace management and buyers at the marketplaces. 
Marketplaces, as one of the main channels of distribution, still have a significant share in the turnover of agricultural products. It is an objective need of the agriculture of Serbia, and its existence should still be counted on. Very significant is the share of marketplaces in the turnover of vegetables (the average for 5 years-76.32\%), dairy products (the average for 5 years-19.01\%), and fruit and grapes (the average for 5 years-39.01\%), while the share of other types of products is insignificant [32]. The high share of marketplaces in the total turnover of vegetables is influenced by numerous factors, which are on the side of production (private sector dominates in its production), as well as by the fact that the buying-up prices, which the producers are offered from buying-up companies, are relatively low in comparison with the level of retail prices of such products. Consequently, the existence of a relatively high difference between the buying-up and retail prices enables that individual producers appear as sellers of their own products [34].

According to the Statistical Office of the Republic of Serbia [35], the total value of the turnover of agricultural products on the marketplaces for the first nine months of 2020, compared to the same period in the previous year, expressed in current prices, is smaller by $8.0 \%$ (due to the pandemic). In the structure of the values of agricultural product turnover on marketplaces for the first nine months of 2020, the following groups of products are represented the most: vegetables (33.5\%), fruit and grapes $(19.4 \%)$, milk and dairy products $(13.8 \%)$, and poultry and eggs $(12.9 \%)$. The data are gathered using the statistical survey "Monthly Report on the Turnover of Agricultural Products on Marketplaces." These reports are complete on an annual basis by the public-utility and other companies whom that provide services such as the leasing of marketplace stalls and other marketplace services. The selling of agricultural products on marketplaces represents the trade, which is done by agricultural holdings directly to the end consumers in arranged (grocery) marketplaces. The turnover that is done on marketplaces by companies (through their retail facilities) and self-employed stores is not considered the turnover in marketplaces and is not taken into consideration in the official statistical data [34]. It is important to note that the majority of marketplace activity in Serbia (around $90 \%$ ) is done by public utility companies founded by municipalities or cities. The aims of this study are focused on answering several important questions:

1. What is the current state of business of the selected marketplace?

2. What is the modern social organization of the selected marketplace?

3. What are the aims of modern market processes, decision making, and trade results of the business management of marketplaces?

4. The present study: Local marketplace "Detelinarska pijaca" in Novi Sad (Serbian second largest city)

Novi Sad, as the second most populated city in Serbia, has a long tradition of organizing marketplace activities. The proclamation of Novi Sad for a free royal city within the Habsburg Monarchy on 1 February 1748, meant that, for the first time, the city was given the right to dispose of the gathered marketplace fees. The historical data shows that the organized trade of food products in the city dates back to the end of the 18th and the beginning of the 19th century [36] and that at the beginning of the 20th, it got its current appearance and business organization (Figures 1 and 2). Since 1952, all the marketplaces on the territory of the city have been organized within the Public utility company (Serbian JKP) "Tržnica", which does its primary activity of providing the conditions through the management, utility equipment, arrangement, and construction of marketplaces to provide regular, quality, and diverse supply of citizens with fresh food products and consumer goods. 


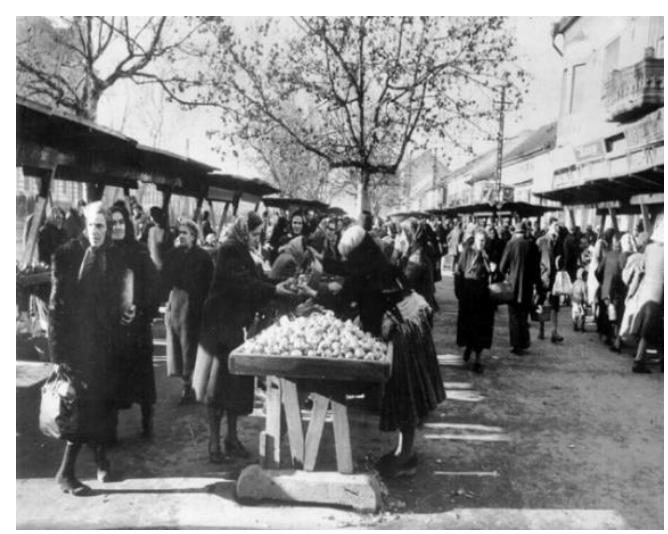

Figure 1. Marketplaces in Novi Sad in the 19th and early 20th century. Source: [37].

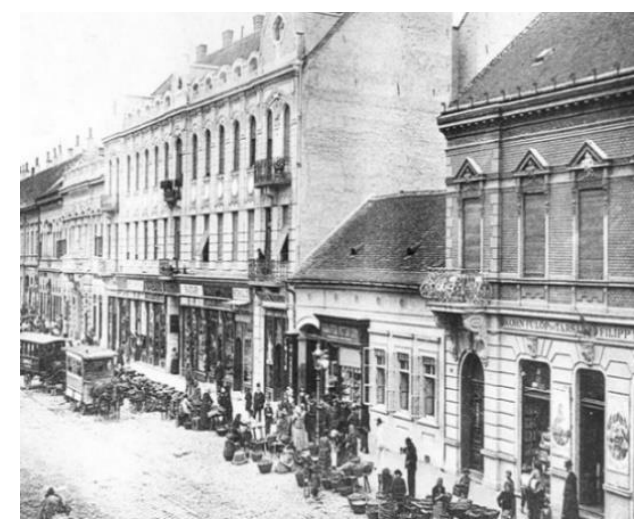

Figure 2. Marketplaces in Novi Sad in the 19th and early 20th century. Source: [37].

The selected location for the research is "Detelinarska pijaca", one of the 10 modern grocery marketplaces in Novi Sad. The marketplace was built in the 1970s on the area of $3000 \mathrm{~m}^{2}$. Today, it comprises 161 sales places and 16 commercial spaces (Figure 3).

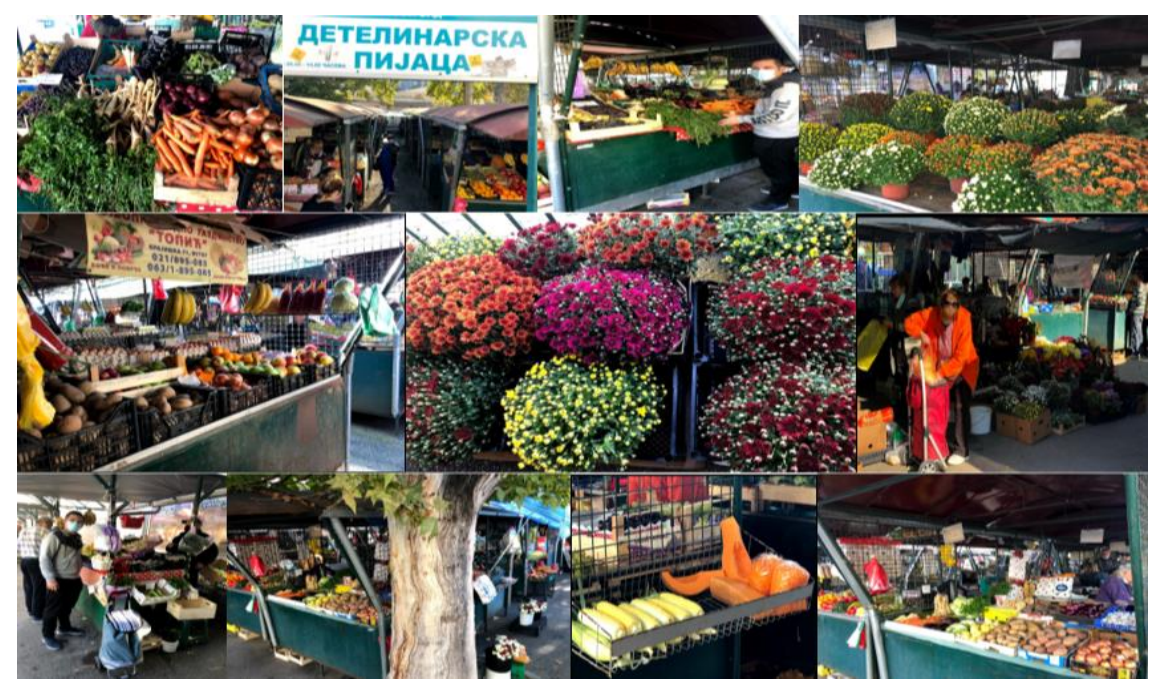

Figure 3. Illustrations from the observed marketplace (Source: Private authors' photos collection, October-December 2020).

The first big reconstruction of the marketplace was done in 2009 when the hall was rearranged, and 10 new shops opened, and at the beginning of 2014, the marketplace was extended with by additional $470 \mathrm{~m}^{2}$ [38], so now it completely meets the needs of 
the citizens and renters. For the last several years, the observed marketplace has been one of the main places for placing goods in this part of Serbia, and a large number of goods / services-offering parties come from the neighboring Croatia, Hungary, and Romania, so the general offer of (non-)agricultural products is quite diverse. The prevailing ones are the characteristic regular and seasonal products of this part of the Pannonian Plain.

\section{Materials and Methods}

The qualitative gathering of data was performed on the selected location on many occasions from October to December 2020. The interviews were undertaken with the vendors and managers of the marketplaces who showed interest in participating in this research. The population for this study consists of 42 respondents (sample size)_four (4) managers and 38 vendors. Qualitative research sample sizes of 10 may be adequate for sampling among a homogenous population [39]. However, other authors claimed that qualitative sample sizes of 20-30 are typically conducted by researchers to establish data saturation using a grounded theory approach to qualitative inquiry [40]. Moreover, Marshall et al. [41] referred to a sample size of 20 as being small for a grounded theory type approach to qualitative research and to 40 being a large sample size for the same type of study, and later in the same paper, authors recommended a range of 20-30 interviews for grounded research and 15 to 30 interviews for case studies. This gives a range of what sample size authors would consider appropriate in qualitative research [42]. In this respect, the sample in this research $(\mathrm{N}=42)$ may be considered adequate for meaningful assessments.

Correspondingly, qualitative methods were selected for the gathering and the examination of the presented data. The decision is also because of the exploratory nature of the research, which key goal is a better understanding of the social organization of the urban marketplace, to complement the literature review undertaken. The selection of choosing qualitative methodologies also follows the modern trend in seller/consumer behavior studies in the field of marketplaces $[2,6,20]$. Bearing in mind that the proposed research suggests investigating and analyzing respondents' attitudes and opinions, the semi-structured individual interview seems to be the suitable technique to collect the data. As Creswell [40] stated, this sort of interview is frequently used in various social research to collect data from interviewees, allowing the valuation of highly idiosyncratic phenomena along with a structured method concentrating on exact themes. In addition, this subsequently supports the identification of patterns and ultimately cases comparisons.

The procedure for the interviews were elaborated based on a theoretical background, covering two major fields: (1) the socio-demographic profile of the respondents; and (2) general questions about the social organization at the marketplace. At the beginning, the respondents were informed about the subject of the research and that the research is anonymous. All relevant statements were written down in the Serbian language, in order to stay as original statements and permit adequate analysis, with minimal loss of information. In addition, all the interviewing data were transcribed, translated into English, and matter to content analysis, including the systematization and categorization of discourses. The collected data were further processed using KH Coder open-source software, and then, based on the theoretical suppositions and participant-observation, clarification of the key issues of each examinees' discourse and the patterns' identification are implemented. The research technique was based on observational research involving the direct observation of examined phenomena in their natural setting.

The purpose of this study is to research the social organization of marketplaces and their current state and management on the example of one of the largest urban marketplaces in Serbia- "Detelinarska pijaca" marketplace. Since such research projects are quite rare in this part of Europe [34], this research could be used for prompting similar research in the future. Also, this research is important because it is one of the first empirical projects on the social organization of marketplaces, modern market processes, decision making, and market outcomes in Serbia. Moreover, Serbian society is currently going through a period of adjusting to the new changes in the labor market, so street vendors play a 
significant role in the current economic processes in trade, as well as in the development of local communities. It could be connected with the global trend of the "return to nature and roots", where the marketplaces, with their offer of agricultural and other products, represent a link between rural environment and urban population.

\section{Results and Discussion}

\subsection{Socio-Demographic Profile of the Sample and Their Expressions of the Meaning of} "Local Marketplace"

The first step in the research regarded the socio-demographic characteristics of the sample. Interviews were undertaken with 42 individuals- 4 managers and 38 vendors. The interviewees are of different ages, educational levels, and residence. Among them, the majority are regular renters present for many years, and most of them are women vendors or couples (husband and wife) of middle-aged or older generations, mainly with completed elementary/middle and high school, from the nearby villages gravitating toward Novi Sad. More details on the socio-demographic structure of the respondents are given in Table 1. The study found that this market fits the profile as those from other studies, as it continues to fill the role of job creation, accumulation of wealth and income for low to middle income families, and it is a place of which fosters entrepreneurial skill development $[5,22,23]$.

Table 1. Sample characteristics (\%).

\begin{tabular}{ccc}
\hline & Men & Women \\
\hline Total: & 45.1 & 54.9 \\
\hline Work Position: & & \\
\hline Manager & 3.5 & 2.7 \\
Vendor & 96.5 & 97.3 \\
\hline Age: & & \\
$\leq$ 20 years & 13.2 & 24.1 \\
21-30 years & 6.0 & 2.3 \\
31-40 years & 18.2 & 5.7 \\
41-50 years & 30.2 & 32.3 \\
51-60 years & 21.1 & 20.8 \\
$\geq 61$ years & 11.3 & 14.8 \\
\hline Education: & & \\
Elementary/Middle School & 36.2 & 47.0 \\
High School & 50.7 & 46.6 \\
Graduate Degree & 10.3 & 6.1 \\
Postgraduate Degree & 2.8 & 0.3 \\
\hline Residence: & & 16.8 \\
City of Novi Sad & 22.4 & 82.8 \\
Surrounding area & 75.1 & 0.4 \\
Other settlements & 2.5 & \\
\hline
\end{tabular}

Source: Data gained in the research.

A key finding from the most frequent terms used by our interviewees (vendors) when asked to define the sense they attribute to the local marketplace has been extracted. The first refers to the quality of the food sold, as "natural products" ( $86 \%$ of responses), aiming at the (in)direct interaction with the countryside they have that makes it possible to offer their customers fresh produce in the urban context. The other most used concepts are similar, "homemade" and "green" (69\% of responses), "agriculture" (54\% of responses), and "rural" (51\% of responses), which connect with and connote a constellation of ideas behind the buyer/seller interest in the market. Other concepts in this constellation are, "return to nature and roots", "pristine environment", "healthy food", and "colors, flavors, and smell" (less than $50 \%$ of responses). These themes are well described by one respondent who affirms that "marketplace" stands for "a special microenvironment in the city, which symbolizes escape from the stress-full surroundings and far from the agitation of the daily life", and more 
poetically, as "a rural oasis in the urban desert", as stated by the second respondent. The state purposes and perceptions of users of the Novi Sad marketplace, as described by Morales [4], demonstrate a desire to support local, green, and sustainable agricultural practices.

Besides the characteristics of the product we learned about the importance of the place and how interactions are characterized. Many of the respondents described the "friendly interaction" ( $41 \%$ of respondents), linked to the communication with customers, and one particularly stating that she appreciates "direct and friendly contact with buyers, mostly traditional and well-known ones, with whom we build a strong bond and trust, which is the primary mission of our business". This demonstrates the importance of the seemingly "warm and close interpersonal contact" for both vendors and their customers when living in contemporary, estranged urban surroundings. These expressions generally reveal the importance of marketplaces allowing a "short escape from tense city life", as expressed in Morales, Balkin, and Persky's [43] study and Morales' [4] findings, as they stress the importance of the "magic" and multiple functions of marketplaces in terms of peoples' respond to the place and activity and how that response renews both individuals and place and can help mitigate social problems.

\subsection{Social Organization/Components of the Observed Marketplace}

The second aspect of research findings regarded the general segments of the social organization of the marketplace. The principal observed social components are associated with the frequency of visits of the interviewees to the selected location and the observation of daily events. Noticeable is the intense interactions between the suppliers and vendors in the early-morning hours, as well as between the vendors and buyers in the morning and early afternoon hours. Even though the marketplaces are open until 5 p.m., most activities are finished by 2 or 3 p.m. Asked about the frequency of the weekly visits and interactions with customers, one of the vendors frames successes as: "If I manage to sell most of my daily products by the noon, I deem my selling as successful. After that time, customers are usually in rush and do not express their interest in buying products in the same amount. Unfortunately, I need to say that "successful days" are not so often". Each day has a recognizable rhythm and vendors have a few common concepts that describe the quality of the interactions they have with customers: "excited" (79\% of responses) and "joyful" (76\% of responses), dominate the quality of the interactions. Interestingly, vendors use the idea of "cohesion" (61\% of responses) to describe the marketplace, and even more interestingly the idea of "recovering energies" (32\% of responses) to describe the results of their work. Unsurprisingly, vendors, being businesspeople, describe there, "needs for new contacts" ( $28 \%$ of responses) and "changing the experiences" (23\% of responses) to show their interest in producing an attractive place that will generate more business. Our findings on the social organization of the marketplace also again align with current market literature that declare marketplaces as environments of social inclusion $[4,10,22]$.

The marketplace manager is always present during the working hours and is in charge of the supervision, the overall organization, product supply, checking of the schedule and agenda, and since March 2020, the important task of the manager has also been the control of hygienic and health measures prescribed by the government authorities to prevent the spread of COVID-19 (wearing masks has been obligatory for all the vendors and visitors of the marketplace since April 2020 until this moment). The controllers are present at all the entrances to the marketplace. This is well illustrated by the following statements: "Every time brings its challenges and issues. Before facing the current, unfavorable epidemiological situation, our main problem in the marketplace was the infrastructural capacities for the undisturbed access and delivery of the items in synchronization with the time and opening of the marketplace for the customers. However current management efforts are primarily focused on the implementation of all hygienic and sanitary conditions because regular controls are performed by the local inspection and the penalties are quite high". Manager flexibility is very important, problems will always surface as well opportunities, and like all businesses the marketplace responds to the 
needs of the moment. These onset challenges induced by the COVID-19 pandemic requires adaptation of strict regulations and controls [30,31].

As to marketplace organization, the vendors have regular rented places/lots, which are visibly marked and with the organized arrangement (Figure 4). Marketplace fees are gathered on a daily or monthly level, it is determined by the length in meters (m), and the price depends on the type of products which are sold and the category to which the sales place belongs to. Each rented space is labeled with the name of the renter, the place where the goods originate from, and the type of product that is usually sold. It is worth mentioning that the majority of respondents $(87 \%)$ have a positive attitude toward the overall organization of the marketplace and the treatment they get from the management, as reported by one vendor in the following terms: "I'm indeed treated as an employee in the well-establish company. We (vendors) are perfectly familiar with our duties but also know our rights, position, and role we have in the marketplace organization".

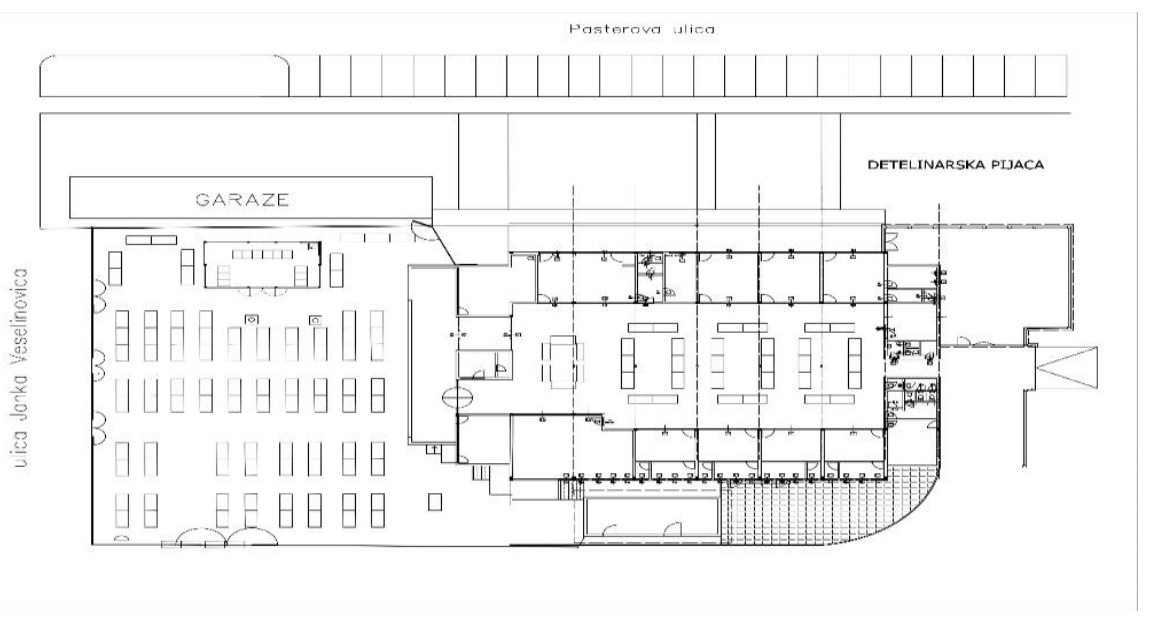

Figure 4. The sketch of the observed marketplace. Source: [38].

The main challenges the respondents are faced with are the following: high monthly prices of space rents; high costs of production and/or buying-up prices of products in comparison with the market prices; insufficient number of buyers on workdays (a significantly larger number at weekends); and the specific problem that the respondents mentioned refers to the irregular street vendors who are not registered and sell products not far from the marketplace location, at significantly lower prices and without any penalties (except the written reprimands) issued by the municipal authorities (Figure 5). Here, the typical issues are highlighted by one interviewee: "Our sales are often on the verge of profitability on a monthly basis, because the earnings are sometimes even lower than the costs we have toward the renter and suppliers. Also, nothing has been done to stop illegitimate competition with lower selling prices (irregular street vendors near the marketplace), whose number is even slightly increasing in the last two-three years". This opinion shares $68 \%$ of the respondents. The rest of the respondents (32\%) believe that mentioned problems do not jeopardize the vital interests of their business and the situation is easily handled. One described it this way: "Despite the high monthly costs of space rents and production of our goods (honey and honey nutritive and cosmetic products in this particular case), my wife and I manage to cover all the costs and earn enough money for our needs. It's not easy, but this is the best option we have for selling our homemade products near to our home, in our local community". However, the same respondent stated, "a bigger concern is the uneven number of customers during the week, i.e., we have a situation where the stand is rented during the whole week, and usually, a real need for sales is only during the weekends (on Saturdays and Sundays morning) because there is still no possibility for daily/weekend rent". Many vendors face a tension between fostering the broader community good and addressing the particular needs they have to earn income. 


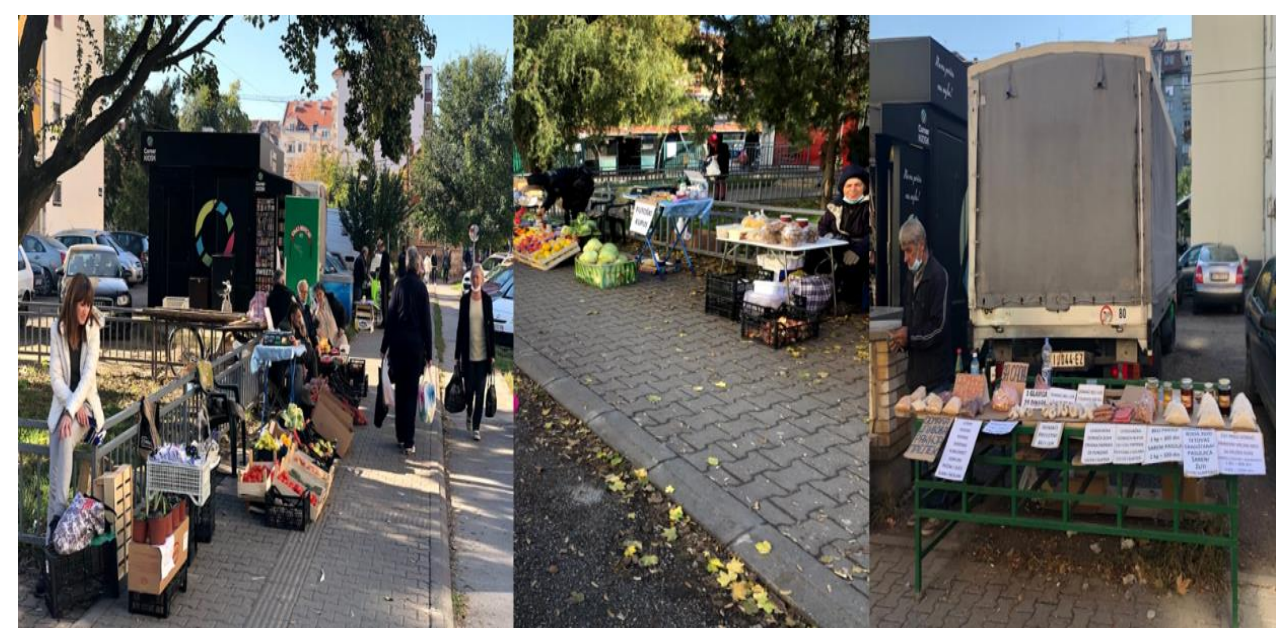

Figure 5. Irregular street vendors near the observed marketplace (Source: Private authors' photos collection made in October 2020).

During the observed period, the typical products sold were seasonal agricultural products, which most often came from the nearby villages and the suburban parts of the city. The products are typically found in the market baskets of Central and Southeastern Europe and they usually include the following food products: cheese, eggs, vegetables (The vegetables characteristic for this area are the following: chard, green beans, broccoli, pumpkin, celery, tomato, onion, garlic, beetroot, pea, cauliflower, kohlrabi, Savoy cabbage, cucumber, potato, cabbage, pepper, beans, common mushroom, carrot, spinach, courgette, lettuce, etc. ), fruit (The fruit characteristic for this area is the following: apple, pear, plum, nuts, apricot, peach, quince, citrus fruit, grapes, fig, strawberry, blackberry, raspberry, sweet and sour cherries, etc), freshwater fish from the Danube River (The most common are common carp, zander, catfish, and sturgeon), other fish (e.g., trout and hake), and other "value-added" products, like honey. Interviews with the vendors revealed that imports of agricultural and other products has significantly decreased since March 2020 in comparison with the previous years, and in some periods imports were completely interrupted. The reason was the unfavorable epidemiological situation present in Serbia and abroad. The current circumstances are articulated by one respondent who affirms that "the global pandemic has significantly affected all segments of the local business this year (2020), and there is a noticeable lack of imported products on the market, especially fruits and vegetables that are not grown in the country. At the same time, this additionally impacted the increase in prices and the structure of product demand, and especially the enhanced demand for products with high vitamins (especially Vitamin $\mathrm{C}$ and $\mathrm{D}$ ) and minerals concentration (e.g., $\mathrm{Zn}, \mathrm{Se}$, and $\mathrm{Mg}$ ), which have been suggested by the media as useful substances for health wellbeing and immunity strengthening. The prices of particular fruits and vegetables have been even doubled raised". This specific finding points to another interesting fact that local marketplaces are very sensitive to the influences of both local demand/impacts and global factors. In short, local food production became more important during the pandemic and possibly help to make the community more resilient and food secure.

The current state of business of the selected marketplace is focused on the contemporary market processes. Sales are characterized by the fact that, mostly, fresh and highquality products are offered, and customers have a possibility of choosing a product, trying it, etc. No matter how high the selling costs for vendors are, they will sell their products immediately as long as they balance the difference above the lower purchase price and higher retail price, and charge for their transport services (they will get more than they would get to stay at home without work), the costs of sales are not sensitive as it is to trade organizations. Prices on the observed marketplace vary significantly depending on the intensity of supply and demand, but are almost always lower than the prices of the same 
products in supermarkets and megastores. This significantly attracts more customers and affects the favorable trade results of the selected marketplace.

The modern organization of the selected marketplace relies on the development of the trade network, which has a great influence on daily business because trade does not include all the surpluses of the individual sector. The structure and quality of production that is realized in the private sector also contribute to the non-capture of market surpluses by the trade network. Very often, and especially when it comes to hyper-production, the quality of products is lower, and retail, due to the high risk that these products carry with them, is not interested in all products. Because of this situation, the manufacturers need to offer them to the marketplace, regardless of what price they will get for the products. A wide range of products in terms of quality has its advantages because in this way the needs of different categories of consumers can be met, considering their level of income. On the other hand, under the influence of the selected marketplace, individual local farmers specialize in the production of certain groups of agricultural products. In this respect, the economic position of farmers becomes better because of the comparative advantages (e.g., proximity to the marketplace, infrastructure, natural conditions, etc.).

The aims of modern market processes in the observed marketplace should be focused on: the function of realization and preservation of common interests and needs of vendors in the field of market activity; establishment of a unified system for informing vendors on all the issues of interest for performing a market activity; providing vendors with professional assistance, especially in the legal and economic fields; creating and encouraging the development of a market activity, using international experiences and achievements, including the field of standardization of market services; working on the enhancements of a market activity, introduction and implementation of modern business models and achievements in this field; working on establishing standards and rules, as well as their application in the field of environmental protection and preservation; working on popularization and practical application of the latest scientific achievements in this field; working on the improvement of informing the general public, organization and implementation of marketing activities; and developing mutual solidarity and reciprocity between vendors in the trade of goods in the markets.

\section{Conclusions}

This paper explored a Serbian market case study as a center of human activity so woven into the fabric of daily life of its users that its many benefits, organization, and uses should not be ignored by scholars and policymakers. These are not "token" activities. This research has reported that this marketplace is an example of a significant micro-economy in Serbia, and more importantly the research profiled an important public space. As supported by the literature, our findings show that marketplaces in Serbia serve many functions beyond the basic economic function of the exchange of goods and services. The findings showed that "Detelinarska pijaca" marketplace represents a key social pillar for the local community of Novi Sad. Additionally, while serving its mission it stimulates small-scale producers by offering in this area original products with the characteristics of high-quality food (e.g., regional brands, food with the labels of geographic origin, organic food, etc.), which is hardly to be found in supermarkets and megastores. Along with the advantages of this traditional and popular distribution channel, the future of the marketplace should adapt and introduce a wider and diverse range of organic food offerings.

At the same time, as the markets are recognized for the important functions they serve, as society becomes increasingly oriented to technology, and as vendors and markets adjust to evolving consumer and community needs, marketplaces should retain and complement their historical identity as places where one can buy fresh fruit and vegetables from the known producers (possibly the vendor at the same time) in the environment that provides the opportunity of meeting people, communication and socialization, especially because marketplaces are the only remaining market institutions which enable direct contact of producers and end consumers. Only marketplaces can offer products "from field to table" on 
the same day. This is one key asset community/government partnerships can build on. Yet, there also needs substantially more research to comprehend the marketplace organization from its many perspectives. Still, it seems that advances in communication complementing the face-to-face of community will make marketplaces important opportunities to help achieve many community goals. The development of marketplace activity should balance, on one side, the further diversification of its activities and products, its infrastructural arrangements, and its equipment and fit to local regulations regarding people's health and food safety, and on the other side the preservation of its flexibility in responding to crisis and opportunities, its integrity, and identity.

For marketplaces in Serbia, it is also important that the public utility model highlighted here should respect the specificities of the marketplace activities to ensure successful markets for communities and vendors. Marketplaces offer communities choice and flexibility. As they look to adapt to the needs of their communities, cities and local governments have an opportunity to adopt policy and practices in data collection and management to celebrate their successes and ensure their survival. Finally, this research is important because it is one of the first empirical projects on this kind in Serbia and this part of Europe. Moreover, Serbian and neighboring societies are currently going through an intensive period of adjusting to the new social and economic changes in the labor market, so local marketplaces and street vendors play a significant role in the current processes of society's transition, as well as in the development of local communities. This could be connected with the global trend of the support and encouragement of entrepreneurs in small businesses (such as local trade) in developing countries. The evident gap in this type of research should be upgraded and put forward in similar marketplaces studies that should be further developed.

Based on our findings, we have identified three key policy recommendations that the local municipal government of Novi Sad can implement. As stated, the primary purpose of the public utility company (Serbian JKP) "Tržnica" is to manage the market, to provide utility equipment, arrangement, and regular, quality, and diverse supply of fresh food products to the citizens of Novi Sad. As a public entity, this marketplace presents lessons for other like-markets that that have the capacity to center the mission of the organization not just on private sector, profit-driven agenda. The first policy recommendation is to increase institutional support of vendors. This could be achieved through links to technical advice for business development and financial training. A second recommendation is for local leaders to embrace the presence of a diverse vendor and customer base as an opportunity to support community development at the markets [10]. Cities could have a presence at the market via public outreach. Lastly, a third policy recommendation would be to incentivize the sale of local, green, and sustainably sourced agricultural products through rent reductions or a tax benefit. As we learned from the case study, this subset of products is an important segment of the goods offered at this market. Nevertheless, our findings showed during the current COVID-19 crisis, vendors have been burdened by high monthly rental rates, and lower profits. They also face the challenges of unregulated street vendor competing for their customer base. Local municipalities must find ways to keep vendors in place at the market while also implementing disincentives through the enforcement of fines for the extra-legal vending operations happening outside the market ground. Instead, those vendors should be welcomed into the market ground through targeted recruitment strategies such as lower rental rates for their initial months at the market.

The main limitation in the research and our suggestion for future studies is to increase the sample size of respondents, so examination of their attitudes and role in local businesses and marketplaces in their local setting might reach higher significance. The second issue that we would like to point out is evident local character of the study (involved only one representative urban marketplace in Serbia), so the future research should involve other marketplaces in the country and from abroad (e.g., neighboring ex-communist countries or similar undeveloped states with active street vendors' role in local trade). That way the entire research would have a greater sample of respondents and data would be more 
relevant and comprehensive for the chosen geographical area and perhaps for the entire country and similar developing societies.

Although there are limitations within this study that demand further research, certain benefits arise from our results. The most important practical implications of this paper are twofold: (a) the results of the research have shown that the potential of urban marketplaces can be enhanced through local authorities' support; (b) as one of the first empirical projects on the social organization of marketplaces, the findings give an overview of modern market processes, decision making, and market outcomes in Serbia. This research can affect future studies to investigate other aspects of marketplaces depending on the difference of regions, on one side, and also alternative opportunities for local development in less-advantaged communities, on the other side. In addition, this supports the research goal to identify the differences and similarities in the marketplace business management conditioned by market trends. Furthermore, it may contribute to future initiatives for the encouragement of this contemporary local/global process.

Author Contributions: Conceptualization, M.D.P., A.M. and E.L.; methodology, M.D.P. and A.M.; validation, E.L.; formal analysis, M.D.P., M.M.R. and S.D.; investigation, M.D.P.; resources, M.D.P., M.M.R. and S.D.; data curation, M.D.P., M.M.R. and S.D.; writing—original draft preparation, M.D.P.; writing-review and editing, A.M. and E.L. All authors have read and agreed to the published version of the manuscript.

Funding: This research received no external funding.

Institutional Review Board Statement: Not applicable.

Informed Consent Statement: Informed consent was obtained from all subjects involved in the study.

Conflicts of Interest: The authors declare no conflict of interest.

\section{References}

1. Ünlü-Yücesoy, E. Constructing the Marketplace: A Socio-Spatial Analysis of Past Marketplaces of Istanbul. Built Environ. 2013, 39, 190-202. [CrossRef]

2. Goff, P.M. Limits to Liberalization: Local Culture in a Global Marketplace; Cornell University Press: Ithaca, NY, USA, 2007; pp. 1-208.

3. Schappo, P.; van Melik, R. Meeting on the Marketplace: On the Integrative Potential of The Hague Market. J. Urban. 2017, 10, 318-332. [CrossRef]

4. Morales, A. Marketplaces: Prospects for social, economic, and political development. J. Plan. Lit. 2011, 26, 3-17. [CrossRef]

5. Faith Ossy, I. Urban Markets in Lagos, Nigeria. Geogr. Compass 2013, 7, 517-526. [CrossRef]

6. Morrison, J. The International Business Environment: Global and Local Marketplaces in a Changing World; Palgrave: London, UK, 2006.

7. Balkin, S. Self-Employment for Low-Income People; Praeger Publishers: New York, NY, USA, 1989; pp. 1-258.

8. Eckstein, L.; Plattner, S. Ethnicity and occupations in Soulard farmers market, St. Louis, Missouri. Urban Anthropol. 1978, 7, 361-371.

9. Sherry, J.F. A sociocultural analysis of a Midwestern American flea market. J. Consum. Res. 1990, 17, 13-30. [CrossRef]

10. Morales, A. Public markets as community development tools. J. Plan. Educ. Res. 2009, 28, 426-440. [CrossRef]

11. Rubdy, R.; Tan, P. (Eds.) Language as Commodity: Global Structures, Local Marketplaces; Bloomsbury Publishing: London, UK, 2008.

12. Janssens, F.; Sezer, C. Marketplaces as an Urban Development Strategy. Built Environ. 2013, 39, 169-171. [CrossRef]

13. Hiebert, D.; Rath, J.; Vertovec, S. Urban Markets and Diversity: Towards a Research Agenda. Ethn. Racial Stud. 2015, 38, 5-21. [CrossRef]

14. Aliaga Linares, L. The Paradoxes of Informalizing Street Trade in the Latin American City. Int. J. Sociol. Soc. Policy 2018, 38, 651-672. [CrossRef]

15. Roever, S.; Skinner, C. Street Vendors and Cities. Environ. Urban. 2016, 28, 359-374. [CrossRef]

16. Bluestone, D.M. “The pushcart evil”: Peddlers, merchants, and New York City's streets, 1890-1940. J. Urban Hist. 1991, 18, 68-92. [CrossRef]

17. Stobart, J.; van Damme, I. Introduction: Markets in Modernization: Transformations in Urban Market Space and Practice, c. 1800-c. 1970. Urb. Hist. 2016, 43, 358-371. [CrossRef]

18. Zandieh, M.; Seifpour, Z. Preserving Traditional Marketplaces as Places of Intangible Heritage for Tourism. J. Heritage Tour. 2020, 15, 111-121. [CrossRef]

19. Braudel, F.; Reynolds, S. The Wheels of Commerce: Civilization and Capitalism 15th-18th Century; Collins: New York, NY, USA, 1983.

20. Toftgaard, J. Marketplaces and Central Spaces: Markets and the Rise of Competing Spatial Ideals in Danish City Centres, c. 1850-1900. Urb. Hist. 2016, 43, 372-390. [CrossRef]

21. Kelley, V. The Streets for the People: London's Street Markets 1850-1939. Urb. Hist. 2016, 43, 391-411. [CrossRef] 
22. González, S. Contested Marketplaces: Retail Spaces at the Global Urban Margins. Prog. Hum. Geogr. 2020, 44, 877-897. [CrossRef]

23. Asante, L.A.; Helbrecht, I. Conceptualising Marketplaces in Anglophone West Africa: A Sexpartite Framework. GeoJournal 2020, 85, 221-236. [CrossRef]

24. Bonanno, A.; Berning, J.; Etemaadnia, H. Farmers Market Locations and Their Determinants: An Empirical Analysis in New England. Agric. Resour. Econ. Rev. 2017, 46, 479-506. [CrossRef]

25. Choo, S. Meeting in the Market: The Constitution of Seasonal, Ritual, and Inter-Cultural Time in Malaysia. Continuum 2011, 25, 619-635. [CrossRef]

26. Pyle, J. Farmers' markets in the United States: Functional anachronisms. Geogr. Rev. 1971, 61, 167-197. [CrossRef]

27. Mayo, J.M. The American Grocery Store: The Business Evolution of an Architectural Space; Greenwood Press: Westport, CT, USA, 1993.

28. Wallerstein, I. The Modern World-System I: Capitalist Agriculture and the Origins of the European World-Economy in the Sixteenth Century; University of California Press: Berkeley, CA, USA, 2011.

29. Marciniak, L. The Social Organization of Merchants' Activities. An Interactionist Study of Urban Marketplaces. Qual. Sociol. Rev. 2020, 16, 106-121. [CrossRef]

30. Asante, L.A.; Mills, R.O. Exploring the Socio-Economic Impact of COVID-19 Pandemic in Marketplaces in Urban Ghana. Afr. Spect. 2020, 55, 170-181. [CrossRef]

31. van Eck, E.; van Melik, R.; Schapendonk, J. Marketplaces as Public Spaces in Times of the Covid-19 Coronavirus Outbreak: First Reflections. Tijdschr. Econ. Soc. Geogr. 2020, 111, 373-386. [CrossRef]

32. Miljković, M.; Alčaković, S. Kanali distribucije poljoprivrednih proizvoda sa posebnim osvrtom na pijace u Srbiji [Distribution channels for agricultural products with an emphasis on the market places in Serbia]. In Synthesis 2015, Proceedings of the International Scientific Conference of IT and Business-Related Research, Singidunum University, Belgrade, Serbia, 16-17 April 2015; pp. 599-602.

33. Duvljak, S. Pravci Razvoja Pijačne Delatnosti u Srbiji [Directions of Development of Market Activity in Serbia]; Poslovno udruženje "Pijace Srbije": Belgrade, Serbia, 2013.

34. Stevanović, S. Razvoj Tržišne Proizvodnje u Poljoprivredi Republike Srbije [Development of Market Production in Agriculture of Republic of Serbia]; DAES (Society of Agrarian Economists of Serbia and University of Belgrade): Belgrade, Serbia, 2009; pp. 1-222.

35. Statistical Office of the Republic of Serbia (2020) Turnover of agricultural products on green markets, III Quarter 2020. Available online: https: / publikacije.stat.gov.rs/G2020/PdfE/G20201323.pdf (accessed on 25 December 2020).

36. Srbulović, Đ.M. Kratka istorija Novog Sada-Treće Dopunjeno Izdanje [A Brief History of Novi Sad-The Third Extended Edition]; Prometej: Novi Sad, Serbia, 2011.

37. JKP “Tržnica", Glavna stranica. Available online: https:/ / www.nstrznica.co.rs / (accessed on 10 December 2020).

38. JKP "Tržnica", "Detelinarska pijaca”. Available online: https://www.nstrznica.co.rs/detelinarska-pijaca (accessed on 10 December 2020).

39. Sandelowski, M. Sample size in qualitative research. Res. Nurs. Health. 1995, 18, 179-183. [CrossRef]

40. Creswell, J.W. Qualitative Inquiry and Research Design. Choosing among Five Traditions; Sage: Thousand Oaks, CA, USA, 1998.

41. Marshall, B.; Cardon, P.; Poddar, A.; Fontenot, R. Does sample size matter in qualitative research?: A review of qualitative interviews in IS research. J. Comput. Inf. Syst. 2013, 54, 11-22. [CrossRef]

42. Boddy, C.R. Sample size for qualitative research. Qual. Mark. Res. 2016, 19, 426-432. [CrossRef]

43. Morales, A.; Balkin, S.; Persky, J. The Value of Benefits of a Public Street Market: The Case of Maxwell Street. Econ. Dev. Q. 1995, 9, 304-320. [CrossRef] 